\title{
Museums, innovative pedagogies and the twenty-first century learner: a question of methodology
}

*Maria Xanthoudaki

\begin{abstract}
The paper aims to build a ground for thinking about museums' role in society and the development of the twenty-first century learner. The first and second parts of the paper focus on the influences technological evolution and current global challenges have brought to our lives, and the consequent requirements for 'new' learning and skills. The third part examines how different elements of new pedagogies and approaches could reinforce the twenty-first century learner and could, moreover, inspire museums. The final part of the paper focuses on the specific contribution that museums could make by integrating their unique identity and approach with elements from the new pedagogies.
\end{abstract}

Key words: Museums; Learning; Twenty-first century skills

\section{Introduction}

In this paper, a large share of the references come from open-access online literature. ${ }^{1}$ It has been a conscious but, in a way, an obliged decision, when I realized that things 'run' so fast that paper journals and books are not enough if one wants to talk about today and tomorrow. I do not wish to make any quality judgment about the literature published on paper (I strongly believe this should not be lost) but rather use this point to draw attention to what is happening around us: the world is moving and changing at great speed. If museums want to remain relevant, they need to be able to grasp the changes and reflect on them before these become outdated.

The paper aims to build ground for thinking about museums' role in society, today but, more importantly, tomorrow. This role has undergone great change and we can certainly recount several different paradigms since the birth of the public museum. Throughout this history, museums have always claimed their importance - in different times more, or less, explicitly, receiving more, or less, recognition by the community - convinced that they can make a difference in people's lives (Museums Association 2013).

It is this 'difference' that I would like to talk about here. What difference can museums make? What difference should they make? And to do this, how are they supposed to think, act, change? I will examine the above questions focusing on the museums' role for individuals' learning and experience and on the ways in which museums can make a difference within the current changing education and learning paradigm.

This is not new. Reflecting on identity, mission and impact has always been a concern for institutions inter-woven with history, culture, society and people, but in these times of change the need is intensifying as museums are trying to reaffirm their role. Worldwide, individuals, institutions and professional networks are trying to "understand the role of museums in the twenty-first century, an understanding that will guide the responsible use of museum resources for our own and future generations' (Roberts 2013: 90). Reflecting on our role helps also push 'the boundaries of what is considered museum work and bring the field closer to the ideal we hold of a socially engaged museum' (Kinsley and Wittman 2013: 3).

In the new global scenario, the notion of social responsibility gains fundamental significance, especially for museum learning professionals (Dierking 2010: 12). Social responsibility is directly linked with the underlying notions of the so-called 'creative economy' 
of the twenty-first century and their implications for learning, in which museums are called to play a transformative role. ${ }^{2}$ As institutions and as museum professionals, we need to know 'what we are there for'. The more we reflect and understand, the stronger our message and our mission become, the clearer our role will appear to us all.

My attempt to reflect on these questions is based on the analysis of the current social and educational context and on a re-interpretation of the role of museums in these new terms. In fact, in the first and second parts of the paper, I discuss the influences technological evolution and current global challenges have brought to our lives, and the consequent requirements for 'new' learning and skills. The third part examines how different elements of new pedagogies and approaches could reinforce the twenty-first century learner and could, moreover, inspire museums. The final part of the paper focuses on the specific contribution that museums could make, integrating their unique identity and approach with elements from these new pedagogies.

Answers might not result for all questions - reflection and change are ongoing; but still, the paper aspires to raise awareness, stimulate discussion and encourage looking ahead to what museums can be for the changing world.

\section{Tales from the near future}

I am not a 'techno-scientist' nor an IT expert, but I don't need to be one to perceive that we do not live, learn and communicate the same way we did just five years ago. Changes in technological platforms are taking place at an impressive speed. Today, digital and networked media provide new possibilities for inter-connectedness, an increased accessibility to knowledge and socialization, and allow for rapid appearance and evolution of new ways to connect, to meet, to learn, to participate, to protest, to (co)create (Black 2012; Bradshaw 2013). ${ }^{3} \mathrm{New}$ relationships between the individual and society are established, artefacts are developed as open-source, and process is valued more than the final product (Price 2013; Honey and Kanter 2013). ${ }^{4}$ These changes encourage the development of a 'culture of participation' in which creative contributions and innovations are invited, supported and decentralized (Fischer 2011).

For the visionary, technology and the outcomes of pioneer research can help people to live more, better and to work less but more efficiently (Palacios-Huerta 2014). At the same time, the more skeptical see technological developments leading to elitism and disempowerment, to surveillance and standardization and to ultimately-scripted scenarios rather than to open access, opportunity and democracy. ${ }^{5}$

Whatever the school of thought, the increasing volume, velocity and variety of data and modes is a fact. Attitudes, methods and systems create new global paradigms and require from each of us to understand them and act at a similar speed. ${ }^{6}$ For the time being however, several people might not be able to catch up and reflect deeply on this change - in the best of cases, the younger ones because they are taken by the enchantment of the 'new'; the older because they might not dare enough. Some people are 'fearful, disengaged and nervous' while others are optimistic about the future - but all of us certainly curious about, as well as accountable for, individual and collective wellbeing and future, ours and that of generations to come (Price 2013: 100; Palacios-Huerta 2014).

Our increased sense of responsibility (as well as concern) stems not only from the 'wonders' of technology, but also from the changing lifestyles and the changing relationship between people and the planet ${ }^{7}$. On the one hand, the economic contraction and growing gap between rich and poor, the increasing rise of the population and the rapid demographic change, as well as youth unemployment, ${ }^{8}$ are strongly affecting people's wellbeing, and human rights and needs, such as living, working, studying, and travelling. On the other hand, the change in consumers' lifestyles means a shift from material goods to activities and services. A 'new' convenience and satisfaction comes from the growing opportunities for access to goods without the need to purchase them outright, while the user experience is perceived as a new form of value (Mahizhnan 1999; Shapiro 2005). ${ }^{9}$

In this context, civic engagement and inclusion are seen as fundamental tools for tackling these challenges and avoiding risks and social unrest. Policies at international level put at the centre of their agenda the need for creating aware, informed and self-confident citizens able to understand and be engaged in tackling these problems (European Commission 2006; Osborn and Dillon 2008; Winnie and Felt 2007). ${ }^{10}$ Wellbeing, democracy and human rights lie in the 
role that self-decisive, independent and aware citizens can have in decision-making and social development while there is an increasing awareness of the need for more inclusive policies and societies. These goals challenge the traditional schooling systems and education models, and require new approaches to building skills, knowledge and understanding.

\section{Tomorrow's children}

From the United States of America to the European Union and as far as Singapore, educators and policy makers are talking explicitly about 'twenty-first century skills and competences' as the tools for the 'twenty-first century citizen': a confident person who has a sense of right and wrong, is adaptable and resilient, knows themself, thinks independently and critically, and communicates effectively ${ }^{11}$ (Pellegrino and Hilton 2012). ${ }^{12}$

Meeting the goal for the new skills and competences means investing in a new approach to school and lifelong education, which promotes skills such as 'critical and systems thinking, information literacy, creativity, adaptability, conscientiousness, persistence, global awareness, self-regulation, cultivation of interests, building of social capital, positive orientation to academic subjects'. ${ }^{13}$ This calls for individualized, self-directed approaches in which learners 'collaborate with educators and with experts in their communities and around the world to customize rigorous learning experiences based on competency and interest instead of time and age'. ${ }^{14}$

Society, for the first time so clearly, acknowledges the importance of - and the need for - a learner qualified (and free) to decide what and how to learn, emerging as expert in their own right. ${ }^{15}$ This is not because we suddenly recognize the value of personalized learning, but because it seems to be the only way to face change. Take the job market, for example: today, 'every middle class job is being pulled up, out or down faster than ever' and there is 'increasingly no such thing as a high wage, middle-skilled job'. ${ }^{16}$ The impact of technological innovation on unemployment increases; in many jobs, persons are gradually replaced by computers, but at the same time a series of new 'emotive occupations' or jobs linked to goods and services are rising (The Economist 2014). This means that young people are ahead of the rest of us in the challenge and have to respond adequately to it. They - the twenty first century citizens - need to be flexible, inventive, entrepreneurial, highly motivated, willing to take risks and capable to innovate because they need to create their own opportunities.

At the same time with the 'start-a-business' / 'invent a job' trend, we also struggle to come to terms with the 'don't go back to school' / 'take a MOOC' novelty. ${ }^{17}$ Educational opportunities expand as a result of a growing demand for lifelong education and the growing offer of learning settings and opportunities, especially with the help of IT. Everyone, from children to the elderly, can potentially study when they want, without having to attend school. Opportunities for personalized, self-motivated education move away from the model of learning organized around stable, usually hierarchical institutions, and demand (as well as cause) change. A new bidirectional relationship between producers and users allows them to be as one and has begun to be applied to a range of fields (Shapiro 2005). ${ }^{18}$

In my view, this is only correct - and inevitable. Schooling has always been criticized for its ineffective approach to learning and understanding, while policy efforts for real change have often remained at pilot level or reached only a few, self-confident and self-motivated teachers (Robinson 2009). The situation is reinforced by the disappointing results in young students' performance in science, technology, engineering and mathematics (STEM), the limited number of careers in these fields (especially in Europe and the US), the growing competition for an ever scarcer number of good jobs for the young, and the increasing difficulty of getting university degrees to lead to a job and a successful future - as well as cases of world-famous university drop-outs (Falk and Dierking 2010). ${ }^{19}$

We live in a world of opposites: on the one hand, we are there to see the high speed in change and ongoing innovation; the 'liberalization' of education opportunities and growing potential of the digital media to expand access to learning; the request for a culture of participation and bottom-up innovation. On the other, we perceive a growing learning divide working against the underprivileged social groups; a widening gap between 'the progressive use of digital media outside the classroom and the no-frills of most public schools that educate our most vulnerable populations', ${ }^{20}$ and even a conscious 'distance-taking' stance towards 
society and its demands. The twenty-first century citizen is a privileged individual for she, potentially, has access to a quality of life never seen before; but she has to strive in order to be able to choose, use, enjoy, understand, participate, personalize, create, in other words, to become the resilient, entrepreneurial, informed, aware and active person required by today's society. And this is a great challenge - maybe the most important of all. In my view, the only way to meet this objective is through education - but seen in a new context, that is, shifting 'the focus of attention from how we should teach to the best ways to learn' for which informal learning - and therefore museums (but not as substitutes of schools) - are invaluable assets (Price 2013: 35).

\section{Innovative pedagogies and the twenty-first century learner}

Informal learning experts and pedagogists should be happier than ever. Current policy and practice seem to acknowledge what they have always argued for - what really matters in learning - and call for a diverse 'learning ecosystem' in which learning adapts to each learner instead of each learner trying to adapt to the instruction mode ${ }^{21}$ (Price 2013; Bell et e. 2009). ${ }^{22}$ In my view, the shift to a learner-centered approach emerges so strongly now because it is the only solution for meeting the twenty-first century skills and competences goals. Current change calls for new attitudes (such as that of twenty-first century citizen) calling for new learning tools, calling for new understandings, calling for change in several fields. You might want to replace 'calling for' with 'causing' but you would have an equally valid circle. Whatever the direction of cause and effect, this has fundamental implications for education and schooling, the ownership of learning, the role of educators and social innovation, while experience, personal interests and values, time and place take up new meanings and roles.

In this context, 'learning philosophies' such as the Kindergarden Learning process, ${ }^{23}$ Open Learning (Price 2013), and of course the widely celebrated Inquiry-Based Learning different but with many common elements - could be seen as a response and, in our case, as useful tools, for museums wanting to address present and future challenges:

(a) Resnick's Kindergarten Learning process is based on the spiraling circle of 'Imagine - Create - Play - Share - Reflect - Imagine'. It does not address pre-schoolers, but introduces a lifelong learning method through experimentation, exploring and testing of boundaries, as well as the ability to share collaboratively. ${ }^{24}$

(b) Open Learning fosters the idea of a holistic vision to learning and is built on active engagement and values: Do it yourself - Do it now - Do it with friends - Do unto others - Do it for fun - Do it for the world to see. Price argues that success and satisfaction can come from taking initiative and responsibility in the social space, building self-confidence and readiness from a culture of service and sharing, and from fun combined with challenge (Price 2013: 108).

(c) Inquiry is by now maybe the most popular 'alternative' teaching and learning approach adopted or recommended by a wide range of reports, policy papers, guidelines for practice and of course institutions and professionals. ${ }^{25}$ In inquiry, learners are invited into a research experience making meaning with the help of reflection, conversation, comparison of findings with others, interpretation of data and observations, and the application of new conceptions to other contexts. ${ }^{26}$

The most important element shared by the three approaches is the role of the learner. All of them draw attention to the importance of a young generation of creators, investigators, actors, improvisers, makers, science-oriented thinkers. The learner is perceived - and valued - as expert and researcher in her own right, growing through personal meaning-making experiences, taking charge of what and how to learn, and seeing herself as a free, active agent in an increasingly de-institutionalized learning environment (Falk and Sheppart 2006). The learner can become the cornerstone, the co-creator of knowledge, but also a self-confident citizen with noble goals: political and civic re-engagement opting for a more equal distribution of wealth, opportunity and power (Price 2013: 22-23). ${ }^{27}$ 
The above arguments and pedagogies and their contribution to the development of twenty-first century skills and competences can, in my view, be further supported by the concept of 'deeper learning' and that of Making (as it is conceived and practiced in the context of the Maker Movement).

Deeper learning is the process through which a person develops the ability to take what is learned in one situation and apply it to new situations (Pellegrino and Hilton 2012: 5). Through deeper learning, 'the person develops transferable knowledge, which includes both expertise in a particular subject area and procedural knowledge of how, why, and when to apply this knowledge to solve unique problems in that subject'. ${ }^{28}$

In my view, deeper learning is a fundamental pedagogical notion for what I am arguing here, because of its potential for 'syntonic' learning; that is, for its contribution to connecting apparently-extraneous knowledge to learners' personal agenda (Papert 2000: 727). According to Papert, 'syntonic' means 'being one with what I am doing' by associating (new) ideas and knowledge with personal identity and a sense of personal power. Knowledge turns thus into something relevant and instrumental for learning and growth, rather than something that comes from 'the outside' (Papert 2000: 727).

'Being one with what I am doing' can be also seen as a distinct characteristic of 'Making', should this be addressed as a learning methodology. Maybe when the Maker Movement was born it did not have a deliberate intention to develop an educational methodology; however, it certainly opted for a conscious change of attitude (Honey and Kanter 2013; Libow Martinez and Stager 2013; Gauntlett 2011). The creation of new things for personal use, the availability (or not) of goods and the need to go beyond the big economic market logic and rules were the reasons for initiating what has today become a world cultural movement brought foreword by makers, Fablabs, ${ }^{29}$ and maker-fairs. But behind those aims there is also the individuals' interest in exploring, experimenting, tinkering with technology and with objects as a way of understanding and learning. ${ }^{30}$

The essence of making lies in something very personal. Makers become 'one with what they are doing' in the sense that they are actively involved, deeply engaged, play, research freely, apply expertise and science-oriented knowledge to new situations in order to pursue and solve personally-meaningful problems, create, innovate. These are elements conducive to theories such as constructivism or situated learning, with specific reference to the museum learning field (Hein 1998; Bevan and Xanthoudaki 2008; Tennant 1997). ${ }^{31}$

At the same time, technology has a strong influence on education and learning practice. Innovative pedagogies and agents emerge - for example, MOOCS, seamless learning, learning analytics, crowd learning, digital scholarship, (serious) gaming, all of them integrating digitally-mediated experiences and technologically-rich environments. They are able to offer new, exciting opportunities, guarantee accessibility and flexibility, and knock down costs and power relationships - but they require (self-)confident users, and skills that were not part of the learners' agenda before. ${ }^{32}$ Learning experience blends into everyday life, cutting across times and locations, and enables high levels of communication and community-building, high speed in searching and processing bits and bytes of information and ongoing, shared change ${ }^{33}$ Although critics see risks for our cognitive learning patterns, empathy, memory and concentration, ${ }^{34}$ pedagogies using technology and the web are clearly linked to the twenty-first century skills and competences:

An educational technology challenge is to support learners in a process of situated meaning making by providing appropriate resources and tools whenever they are needed, allowing a learning activity to be suspended and resumed, enabling learning activities to be interwoven, harnessing the power of everyday social interaction so that people can create composite lifelogs of shared events, and learners are able to scroll back in time to recall previous activities and outcomes. ${ }^{35}$

On this basis, I would like to reflect on contemporary museums' contributions in preparing the contemporary citizen. 'The question now is how society, including museums, will face this new situation and find a new equilibrium' (Janes 2011: 138). 


\section{Museums change lives}

In the quest for the twenty-first century learner, the belief that 'museums can change people's lives' becomes even stronger (Museums Association 2013). Museums have seen the value of a learner-centered approach before several other educational institutions; that is, they have been very early in espousing a philosophy that now seems to be the (only?) one necessary for future success (Wood and Wolf 2008, Hein 1998; 2006; Falk and Dierking 1992; 2000). In my view, museums can make a difference because they are able to instill a methodology which is part of their very nature, integrated in the things they do well, do for a long time, and are unique at doing, for which they are widely recognized, appreciated and trusted, and which can be the key for building twenty-first century skills.

\section{A methodology for syntonic experiences - or 'back to the basics'}

I have talked about the value of engaging visitors with experience inquisitively, experimentally, actively and directly - and most museums worldwide have been working towards this goal. The inquiry-based learning approach has introduced, in an explicit and powerful way, methodological principles and tools for strengthening learners' knowledge and skills, but also for building their self-confidence and critical stance. In other words, learning through inquiry promotes an attitude; it helps make the scientific method a 'modus pensandi' for all individuals - and not only in science-oriented learning experiences.

However, when considering the twenty-first century citizen and their success in the future, we need to reinforce the benefits of inquiry-based learning drawing on other methodologies. In my view, encouraging learners to 'become one with what they do' is a powerful tool for twentyfirst century skills such as thinking and acting creatively and innovatively, self-management and independence, persistence, resilience, deep learning, entrepreneurship. ${ }^{36}$ Learning acquires thus a new expanded definition, that of a process of 'being - knowing - becoming', moving away from the 'mere memorization of abstract or detached facts to the mastery of things and to an affinity for, and fluency in, the ways of knowing-being-becoming' (Petrich et al. 2013: 53).

In this context, I find that the spirit and practices of Making constitute an enormous opportunity, both for learners and for educators. Making and/or Tinkering activities are by now a well-established activity in many museums ${ }^{37}$ (and other settings). The two share many common elements - i.e. the hands-on relationship with objects and technology, a strong underlying scientific dimension, a creative dimension, the centrality of the individual in the whole process - but, in my view, are quite distinct when used as learning methodologies. Tinkering addresses all learners, including those 'that do not think of themselves as tinkerers or "good at science" and requires a very low-skill entry level (Petrich et al. 2013: 52). It is a creative inter-disciplinary approach to science and technology. In Wilkinson's and Petrich's own words:

It is thinking with your hands and learning through doing. It is slowing down and getting curious about the mechanics and mysteries of everyday stuff around you. It is whimsical, enjoyable, fraught with dead ends, frustrating, and ultimately about inquiry. It is also about making something and that thing reveals itself to you as you go. Because when you tinker, you are not following a step-by-step set of directions that leads to a tidy end result (Wilkinson and Petrich 2014: 13).

What is most valuable for my arguments here is the so-called Tinkerers' disposition - i.e. that state of mind of taking oneself through a process of exploring a problem rather than solving it (Petrich et al. 2013, Bevan et. al. 2015). The Tinkerers' disposition is a powerful tool for creating syntonic experiences because:

- $\quad$ the strong personal dimension invites learners to build and become one with their own project, to create a 'conversation with the material' (Schoen 1983 in Resnick and Rosenbaum 2013: 165)

- the creative nature of experience encourages learners to pursue a new project, a new goal, a new idea, cultivating the spirit of innovation; 
- the sensorial and manual nature of experience supports those skills that the technology-skeptics fear could be $\operatorname{los}^{38}$ - and indeed museums do a lot regarding this already;

- the inter-disciplinary nature of experience allows learners to use science and technology in an indirect, integrated, equally efficient way;

- $\quad$ asking questions such as 'I wonder how it works', 'I wonder what would happen if I did this' means asking questions asked by scientists too, that form the basis of the scientific process (Semper 2014: 10);

- the 'being-in/stepping back' nature of the activity invites the learner to reflect at metacognitive level.

Similarly, making gets you to decompose and compose things, 'look inside' technology, create your own objects, feel - and become - the creator and producer of your own goods - taking one step further. Some tools for Making might be considered 'black boxes'; that is, not immediately possible to understand or to use and requiring a bit of expert knowledge and/or mediation. But instead of (mis)understanding them as barriers to wide access, they could sow the desire to reach new levels of technology-oriented understanding or sophisticated knowledge and expertise. ${ }^{39}$

Such experiences introduce a new kind of learning, for they build an inherent confidence in one's ability to learn and understand (Petrich et al. 2013: 53-54; Bevan et al. 2015). ${ }^{40}$ In museums, tinkering - as well as making and inquiry-based - activities acquire a unique dimension, not only because they build on their already-strong learner-centred approach, but also because they enhance museums' profound capabilities to create 'personally meaningful and potentially transformative experiences' and a 'new, interesting and surprising glimpse into past, present and potential worlds' (Beghetto 2014:3). By creating the conditions for these kinds of experiences, museums contribute to a new approach to life: one which does not depend on what you know or how much you know, but on the ability to come up with innovative solutions.

\section{A methodology for understanding the unknown - or 'back to the future'}

Growing up, children learn because they desire'; they desire to understand how the world around them works, they desire to change, they desire to build relationships and to communicate with others; 'they desire the unknown'. ${ }^{41}$ Today, the 'unknown' is maybe more unknown than ever before. Public consultations reveal skepticism towards change in jobs, education, technology, public service etc., and a loss of trust in business and governments across the world. At the same time however, distrust often becomes the driver for a stronger civic responsibility and public involvement in the shaping of the future. ${ }^{42}$

Global challenges need prepared citizens. Museums are among the ones to 'encourage people to think about the future by understanding its context' (Blatchford 2014). They create opportunities to discuss the new, to follow the speed of change, and to understand that each individual has an active role in the system. The 'Science \& Society' 'movement' in science communication - now widely adopted by, and consolidated in, museums - was meant to build awareness of, and engagement in, cutting-edge and socially-relevant issues, and to help move from 'being compliant citizens (being told what is good for us) to informed actors who are determining our own futures' (Price 2013: 195; Gibbons et al. 1994; Norothy et al. 2003).43

But, again, we need more than that if we are to help the twenty-first century learner. Museums should make an effort to encourage learners 'to put [themselves] outside the comfort zone, working through [their] doubts and fears' (Price 2013: 158), cultivate in them the desire to explore the unknown, make it part of their own experience, even when it does not seem to belong in it.

Museums, driven by their expertise, scholarship and authority, but also by their great sensitivity to the 'rights' of the learner (Xanthoudaki 2013), can be the ones offering opportunities to encounter the new, understand the context and reflect on their role within the system. 'Embracing uncertainty' (Price 2013) means building on skills such as resilience, adaptability, conscientiousness, leadership and responsible decision-making, as well as global awareness. 
In this sense, technology, digital engagement, the web, social media, and games should be seen both as subject matter and as the new means for widening access and enriching learning experiences. Today, even though technology is criticized for creating a 'mono-brain', ${ }^{44}$ it is increasingly becoming part of our lives. It is a driving factor aiming at 'increasing efficiency, increasing opportunity, increasing emergence, increasing complexity, increasing specialization, increasing ubiquity, increasing freedom, increasing beauty, increasing sentience, increasing structure, increasing evolvability'. ${ }^{45}$ Museums need to create contexts through which learners are able to explore what this means. This does not imply using digital narrative in museum exhibitions; but creating opportunities for exploring the potential of technology for re-interpreting contents and creating meaning that can be shared with the world. ${ }^{46}$

In other words, learners should be able to use technology to build socially-based, actively- and cooperatively-constructed contextualized knowledge and webs of relations, pursuing personal goals and motivation through a course of personal change (Salomon and Almog 1998). For museums, this becomes not only a question of building awareness and understanding of the ever smarter phones and cars or the helpful glasses, but of creating opportunities for discussing the directions in which technological evolution is taking us (as we assume biological evolution does). ${ }^{47}$

At the same time, it means that museums should insist on talking about cutting-edge scientific developments, upcoming research questions, and the nature of science, however difficult, controversial or upsetting the discussion of all this might be - because they are among those institutions able to bridge the gap between contemporary science practice and the history of science. According to Blachford:

There are two crucial things about a museum. One is that museums help people understand how discoveries were made in the past and what we can learn about the creative personalities involved. But also about how problems re-emerge, [...] how problems repeat. Ethical issues, how society makes choices are the same now as they were in the 1500s or the 1800s. [...] Museums are the hinge of history. It is where relevant historical collections and modern challenges can meet and be understood better (Blachford 2014).

On the other hand, embracing uncertainty also means embracing a creative attitude. Taking risks is not explicitly mentioned in the documents about twenty-first century skills, but flexibility and adaptability are. We cannot succeed by not failing, however, very often we remove failure from what learners do. Learning to understand mistakes means facing them as a learning opportunity rather than a catastrophe, and potentially turning them into creativity, that is, into the capacity to build original ideas that can be valued (McArdle 2014; Robinson 2009).48

Museums' approaches to learning create ideal requisites for valuing failure as a learning tool: inquiry-based learning experiences often include error and failure in the process of pursuing a research question; tinkering and making activities cherish them as powerful tools to progress through messy situations involving continuous experimental trials of different solutions (Resnick and Rosenbaum 2013: 165); personal meaning-making experiences have no wrong answers. Museums welcome the productive interaction with the subject matter through 'interpreting meanings, formulating questions, choosing and adapting a method, designing an apparatus' (Greeno 2006 in Bevan and Xanthoudaki 2008: 110). Failure and risk constitute an integral part of the learning experience aiming at exploring novel solutions and meanings, and at offering opportunities for personal reflection and skills progression. ${ }^{49}$

All the above should concern all learners - of all ages and walks of life. Museums' contribution to strong and resilient communities and to creating modern 'societies of all ages' means providing for the younger generations who need to create job opportunities and be ready for the future, but also for the older ones, who are still today, and will continue to be for some time, twenty-first century citizens. ${ }^{50}$

The accelerating demographic aging ${ }^{51}$ means older generations are potentially socially active for longer than before. People today live longer and can represent a significant resource for society, and have a wealth of knowledge, experience, time and energy to contribute to modern societies as citizens, volunteers, workers, family members and consumers (PalaciosHuerta 2014). ${ }^{52}$ Society needs, therefore, to provide new forms of growth opportunity and 
guarantee opportunities and quality of life for an increasing number of older people, updating their skills and helping them combine their existing knowledge and competencies with the rapidly evolving needs of society.

In this case, in museums older, and surely all people, should be able to feel comfortable not to know. They - as much as younger learners - can come together to debate the future, consider new propositions and evaluate the various development moves that are changing the social context everyday. The museum should become a safe, informal and respectful gathering place where all feel confident to face the unknown. ${ }^{53}$

\section{Working on a dream}

Are museums the solution to all problems? I wish we could answer yes. But even though we cannot, we should ask ourselves how we can do more. To be able to change people's lives, museums 'must be put in the picture, not just in the frame' of the emerging pedagogies and the global challenges. ${ }^{54}$ To do this, they need to build on what they are uniquely able to offer: their astonishing technical expertise in collecting, researching, safeguarding, studying, interpreting, displaying, communicating, engaging with cultural heritage; and their profound capabilities in 'telling stories, at eliciting emotion, at triggering memories, at stirring imagination, at prompting discovery'. ${ }^{55}$ And they also need to make public value an even more explicit goal. From my point of view, museums, whatever their focus, have the responsibility to help individuals engage in learning not only about their collections, exhibitions or programmes, but think about their lives through those.

Museums should evolve from 'irresistible' to 'irreplaceable' - and, even more, from 'essential' to 'addictive', that is, to places that people can live without, but do not want to. ${ }^{56}$

Received:11 October 2014

Finally Accepted: 6 March 2015

\section{Notes}

1 Online literature means website and blog posts, newspaper articles, open-source documents all of which came to my attention through professional groups and websites, twitter and other social media communications and conferences. All references are included in the bibliography or endnotes and are of course in addition to paper journals and books.

2 Peel, Y., 'How Museums Can Transform the Art of Learning', CNN Business360, 24 January 2013, business.blogs.cnn.com/2013/01/24/how-museums-can-transform-the-artof-learning/, accessed on 12 February 2014.

3 Ito, M., Gutiérrez, K., Livingstone, S., Penuel, B., Rhodes, J., Salen, K., Schor, K., SeftonGreen, J. and Watkins, C.J., (2013), Connected Learning: An Agenda for Research and Design, Irvine, CA: Digital Media and Learning Research Hub, http://dmlhub.net/publications;

American Association of Museums, (2012), TrendsWatch 2012: Museums and the Pulse of the Future, http://www.aam-us.org/docs/center-for-the-future-of-museums/2012 trends watch final.pdf?sfvrsn=0;

4 Meritt, E. and Katz, P.E., (2013), TrendsWatch 2013: Back to the Future, American Alliance for Museums Centre for the Future of Museums, http://aam-us.org/docs/center-for-thefuture-of-museums/trendswatch2013.pdf.

McDermott, J., (2014), 'Throw off the High-Tech Bracelets and See Through Google Glass', Financial Times, 10 January, http://www.ft.com/int//cms/s/0/0c36c742-7928-11e3-b38100144feabdc0.htm|\#axzz2u4WfFR2F.

Ito, M., Gutiérrez, K., Livingstone, S., Penuel, B., Rhodes, J., Salen, K., Schor, K., SeftonGreen, J. and Watkins, C.J., (2013), Connected Learning: An Agenda for Research and Design, Irvine, CA: Digital Media and Learning Research Hub, http://dmlhub. net/publications; 
Waters, A., 'Hacking at Education: TED, Technology Entrepreneurship, Uncollege, and the Hole in the Wall', Hack Education blog 2013, http://hackeducation.com/2013/03/03/ hacking-your-education-stephens-hole-in-the-wall-mitra/, accessed 26 February 2014.

5 Cohen, H., (2013), The Internet's Verbal Contrarian, New York Times, 14 August, http://www.nytimes.com/2013/08/15/business/media/the-internets-verbal-contrarian.

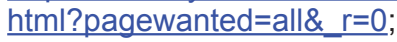

Waters, A., 'Hacking at Education: TED, Technology Entrepreneurship, Uncollege, and the Hole in the Wall', Hack Education blog 2013, http://hackeducation.com/2013/03/03/ hacking-your-education-stephens-hole-in-the-wall-mitra/, accessed 26 February 2014.

6 Rampini, F., (2014), 'Web Power: L'Acquisizione miliardaria di WhatsApp da parte di Facebook non è che l'ultimo tassello di una rivoluzione', La Repubblica, 21 February 2014 http://www.repubblica.it/tecnologia/2014/02/20/news/10 motivi acquisto whatsapp facebook-79153148/;

Knowledge Works Forecast 3.0 'Recombinant Education: Regenerating the Learning Ecosystem', http://knowledgeworks.org/future-of-learning, accessed 20 February 2014.

7 I do not discuss here environment-oriented challenges such as climate change, energy (in)sufficiency and sources, food safety and security, health, consuming. Although these are directly related to scientific research and technological development, are not the focus of this paper.

873 million young people were estimated to be out of work in 2013 (International Labour Organization), http://www.ilo.org/global/topics/youth-employment/lang--en/index.htm, accessed 14 February 2014.

9 Caragliu, A., Del Bo, C. and Nijkamp, P., (2009), 'Smart cities in Europe', 3rd Central European Conference in Regional Science proceedings, http://inta-aivn.org/images/cc/ Urbanism/background\%20documents/01_03_Nijkamp.pdf

Centre of Hitachi, (2012), Hitachi's Vision of the 'Smart city': Seeking a Well-balanced Relationship between People and the Earth, White Paper, http://www.hitachi.com/products/ smartcity/download/pdf/whitepaper.pdf;

Berthon, B., Massat, P. and Collinson, S., (2011), Building and Managing an Intelligent City, Accenture, http://www.accenture.com/SiteCollectionDocuments/PDF/Accenture-BuildingManaging-Intelligent-City.pdf;

Dirks, S., Gurdgiev, C. and Keeling, M., (2010), Smarter cities for smarter growth: How cities can optimize their systems for the talent-based economy, IBM Institute for Business Value, Executive Report, http://public.dhe.ibm.com/common/ssi/ecm/en/gbe03348usen/ GBE03348USEN.PDF.

10 European Commission, (2013), Erasmus+ Programme Guide, http://ec.europa.eu/ programmes/erasmus-plus/documents/erasmus-plus-programme-guide en.pdf.

See also the policy and strategy of the European Union: http://ec.europa.eu/europe2020/ index it.htm; http://ec.europa.eu/education/policy/strategic-framework/index en.htm.

11 Ministry of Education Singapore, 'MOE to Enhance Learning of 21st Century Competencies and Strengthen Art, Music and Physical Education', press release, 2010, http://www.moe. gov.sg/media/press/2010/03/moe-to-enhance-learning-of-21s.php. 
12 Ito, M., Gutiérrez, K., Livingstone, S., Penuel, B., Rhodes, J., Salen, K., Schor, K., SeftonGreen, J. and Watkins, C.J., (2013), Connected Learning: An Agenda for Research and Design, Irvine, CA: Digital Media and Learning Research Hub, http://dmlhub.net/publications;

Peel, Y., 'How Museums Can Transform the Art of Learning', CNN Business360, 24 January 2013, business. blogs.cnn.com/2013/01/24/how-museums-can-transform-the-artof-learning/, accessed on 12 February 2014;

Knowledge Works Forecast 3.0, 'Recombinant Education: Regenerating the Learning Ecosystem', http://knowledgeworks.org/future-of-learning, accessed 20 February 2014;

Sutcliffe, H. (2011) A Report on Responsible Research and Innovation, prepared for DG Research of the European Commission, http://ec.europa.eu/research/science-society/ document library/pdf 06/rri-report-hilary-sutcliffe en.pdf;

Financial Times (2014) Investing in Young People, FT Special Report 24 January, http:// www.ft.com/int//reports/invest-young-people.

13 Ito, M., Gutiérrez, K., Livingstone, S., Penuel, B., Rhodes, J., Salen, K., Schor, K., SeftonGreen, J. and Watkins, C.J., (2013), Connected Learning: An Agenda for Research and Design, Summary Report, Irvine, CA: Digital Media and Learning Research Hub, http:// dmlhub.net/sites/default/files/ConnectedLearning_summary.pdf. See p. 6.

14 Knowledge Works Foundation, '2020 Forecast: Creating the Future of Learning', 2008, http://www.knowledgeworks.org/sites/default/files/2020-Forecast.pdf.

15 The issue of people with special needs or of those with limited motivation is of particularly importance when speaking aboutemerging learner-centered approaches or dis-intermediated social processes; it needs therefore a dedicated study for all related education- and policyoriented aspects to emerge and be discussed properly.

16 Friedman, T.L., (2013), 'Need a Job? Invent it', New York Times, 30 March, http://www. nytimes.com/2013/03/31/opinion/sunday/friedman-need-a-job-invent-it.html.

17 Financial Times (2014) Investing in Young People, FT Special Report 24 January, http:// www.ft.com/int//reports/invest-young-people;

Waters, A., 'Don't Go Back to School... Or Do', Hack Education blog 2013, http:// hackeducation.com/2013/04/16/dont-go-to-school-or-do/;

On MOOCS (Massive Open Online Courses) and other online courses see: http://www. nytimes.com/2012/07/17/education/consortium-of-colleges-takes-online-education-to-newlevel.html? r=1\&; https://www.coursera.org/; http://online.wsj.com/article/SB1000142412 7887324906004578288341039095024.html.

18 Centre of Hitachi, (2012), Hitachi's Vision of the 'Smart city': Seeking a Well-balanced Relationship between People and the Earth, White Paper, http://www.hitachi.com/products/ smartcity/download/pdf/whitepaper.pdf;

Berthon, B., Massat, P. and Collinson, S., (2011), Building and Managing an Intelligent City, Accenture, http://www.accenture.com/SiteCollectionDocuments/PDF/Accenture-BuildingManaging-Intelligent-City.pdf;

Dirks, S., Gurdgiev, C. and Keeling, M., (2010), Smarter cities for smarter growth: How cities can optimize their systems for the talent-based economy, IBM Institute for Business Value, Executive Report, http://public.dhe.ibm.com/common/ssi/ecm/en/gbe03348usen/ GBE03348USEN.PDF. 
We can see such bidirectional relationship in the field of IT: people can transmit information as easily as they can receive it and can search the internet for information as easily as they can create their own blog to provide it; or, in the energy field, an increasing number of people install their own photovoltaic power generation and can thus act as both a consumers and suppliers.

19 Ito, M., Gutiérrez, K., Livingstone, S., Penuel, B., Rhodes, J., Salen, K., Schor, K., SeftonGreen, J. and Watkins, C.J., (2013), Connected Learning: An Agenda for Research and Design, Irvine, CA: Digital Media and Learning Research Hub, http://dmlhub.net/publications.

See also Verhart, B., (2012), 'Education is Failing the Future-Makers', WIRED, February, 53-54, http://www.wired.co.uk/magazine/archive/2012/02/ideas-bank/education-is-failing; OECD, (2006), Science Competences for Tomorrow's World, PISA Report, http://www. oecd.org/dataoecd/15/13/39725224.pdf;

Financial Times (2014) Investing in Young People, FT Special Report 24 January, http:// www.ft.com/intl/reports/invest-young-people.

We all share the urge to introduce new teaching and learning approaches more in line with contemporary needs - but we should not arrive at the other extreme. Attempts to convince us that schools can be easily substituted by other education schemes or just cease to exist could lead to dangerous misconceptions about their value and to serious risks of new types of exclusion (Waters blog 'Hacking at Education...').

20 Ito, M., Gutiérrez, K., Livingstone, S., Penuel, B., Rhodes, J., Salen, K., Schor, K., SeftonGreen, J. and Watkins, C.J., (2013), Connected Learning: An Agenda for Research and Design, Irvine, CA: Digital Media and Learning Research Hub, http://dmlhub.net/publications. See p. 7.

21 Knowledge Works Forecast 3.0 Forecast, 'Recombinant Education: Regenerating the Learning Ecosystem', 2008, http://knowledgeworks.org/future-of-learning, Accessed 20 February 2014.

22 For further discussions about learning see: Xanthoudaki, M., (2010), Quality Science Education: Where Do We Stand? Guidelines for Practice from a European Experience, Museo Nazionale della Scienza e della Tecnologia Leonardo da Vinci, Lifelong Learning Programme of the European Union, www.museoscienza.org/setac/resources.asp;

Fenichel, M. \& Schweingruber, H.A., (2010), Surrounded by Science: Learning Science in Informal Enrivonments, Centre for Education, Division of Behavioral and Social Science and Education, Washington DC.: The National Academies Press, http://www.nap.edu/ catalog.php?record id=12614;

Centre for the Future of Museums, 'The Next Era of Education Will Be What?' 2011 http:// futureofmuseums.blogspot.de/2011/06/next-era-of-education-will-bewhat.html, Accessed 15 February 2014;

European Commission, (2013), Erasmus+ Programme Guide, http://ec.europa.eu/ programmes/erasmus-plus/documents/erasmus-plus-programme-guide en.pdf.

See also www.exploratorium.edu/lFl/resources/constructivistlearning.html; http://caise. insci.org/news/99/51/ISE-Summit-2010/d,resources-page-item-detail; $\underline{\text { http://www.nap.edu/ }}$ openbook.php?isbn=0309053269; http://www.nsf.gov/pubs/2000/nsf99148/pdf/nsf99148. pdf; http://www.inspiringlearningforall.gov.uk/;

23 Resnick, M., (2007), 'All I Really Need to Know (About Creative Thinking) I Learned (By Studying How Children Learn) in Kindergarten', Creativity and Cognition Conference, http:// web.media.mit.edu/ mres/papers/kindergarten-learning-approach.pdf. 
24 Resnick, M., (2007), 'All I Really Need to Know (About Creative Thinking) I Learned (By Studying How Children Learn) in Kindergarten', Creativity and Cognition Conference, http:// web.media.mit.edu/ mres/papers/kindergarten-learning-approach.pdf.

25 High Level Group on Science Education, (2007), Science education NOW: A renewed pedagogy for the future of Europe, DG Research, http://ec.europa.eu/research/sciencesociety/document library/pdf 06/report-rocard-on-science-education en.pdf;

National Science Foundation Division of Elementary, Secondary, and Informal Education (ESIE), Inquiry: Thoughts, Views, and Strategies for the K-5 Classroom, Volume 2, http:// www.nsf.gov/pubs/2000/nsf99148/pdf/nsf99148.pdf. For a discussion on inquiry see also: The Exploratorium Institute of Inquiry 'A Description of Inquiry', 1998, http://www. exploratorium.edu/IFl/about/inquiry.html.

26 Xanthoudaki, M., (2010), Quality Science Education: Where Do We Stand? Guidelines for Practice from a European Experience, Museo Nazionale della Scienza e della Tecnologia Leonardo da Vinci, Lifelong Learning Programme of the European Union, www. museoscienza. org/setac/resources.asp.

27 Ito, M., Gutiérrez, K., Livingstone, S., Penuel, B., Rhodes, J., Salen, K., Schor, K., SeftonGreen, J. and Watkins, C.J., (2013), Connected Learning: An Agenda for Research and Design, Irvine, CA: Digital Media and Learning Research Hub, http://dmlhub.net/publications.

The more we adopt personalized learning approaches or citizen-centred policies, the more assessment emerges as a need. Indeed, several attempts to assess the complex nature of learner-centred approaches have been made, in the museum field as well. See, for example, the Personal Meaning Mapping tool (Caban et al. 2003; in Adelman et al. 2000); or the Learning and Facilitation Framework devised by the Exploratorium Tinkering Studio at http://tinkering.exploratorium.edu/learning-and-facilitation-framework.

28 National Academies, 'Transferable Knowledge and Skills Key to Success in Education and Work; Report Calls for Efforts to Incorporate 'Deeper Learning' Into Curriculum', Press release 10 July 2012, http://www8.nationalacademies.org/onpinews/newsitem. aspx?RecordID=13398, accessed 2 March 2014.

29 For a more detailed definition of a FabLab see http://www.fabfoundation.org/fab-labs/whatis-a-fab-lab/. According to the FabLab Foundation, 'a Fab Lab is a technical prototyping platform for innovation and invention, providing stimulus for local entrepreneurship. A Fab Lab is also a platform for learning and innovation: a place to play, to create, to learn, to mentor, to invent. [...] A Fab Lab is comprised of off-the-shelf, industrial-grade fabrication and electronics tools, wrapped in open source software and programs written by researchers at MIT's Center for Bits \& Atoms. [...] Originally designed for communities as prototyping platforms for local entrepreneurship, FabLabs are increasingly being adopted by schools as platforms for project-based, hands-on STEM education. Users learn by designing and creating objects of personal interest or import. Empowered by the experience of making something themselves, they both learn and mentor each other, gaining deep knowledge about the machines, the materials, the design process, and the engineering that goes into invention and innovation. In educational settings, rather than relying on a fixed curriculum, learning happens in an authentic, engaging, personal context, one in which students go through a cycle of imagination, design, prototyping, reflection, and iteration as they find solutions to challenges or bring their ideas to life'.

30 Vossoughi, B. and Bevan, B., (2014), Making and Tinkering: Review of the Literature, Paper Commissioned by the Board on Science Education, National Academy of Sciences, http:// sites.nationalacademies.org/DBASSE/BOSE/CurrentProjects/DBASSE_086842, accessed 27 January 2015. 
31 Vossoughi, B. and Bevan, B., (2014), Making and Tinkering: Review of the Literature, Paper Commissioned by the Board on Science Education, National Academy of Sciences, http:// sites.nationalacademies.org/DBASSE/BOSE/CurrentProjects/DBASSE_086842, accessed 27 January 2015;

Smith, M. K., (2003, 2009), 'Jean Lave, Etienne Wenger and Communities of Practice', The encyclopedia of informal education, retrieved from www.infed.org/biblio/communities of practice.htm.

32 Edgecliffe-Johnson, A. and Cook, C., (2013), 'Education: From blackboard to Keyboard', Financial Times, 17 January, http://www.ft.com/int//cms/s/0/8de6072c-60a0-11e2-a31a00144feab49a.html\#axzz2xRMcKT7Q;

Sharples, M., McAndrew, P., Weller, M., Ferguson, R., FitzGerald, E., Hirst, T. and Gaved, M., (2013), Innovative Pedagogy 2013, Open University, http://www.open.ac.uk/personalpages/ mike.sharples/Reports/Innovating_Pedagogy report 2013.pdf, accessed 3 March 2014;

Waters, A., 'Hacking at Education: TED, Technology Entrepreneurship, Uncollege, and the Hole in the Wall', Hack Education blog, 2013, http://hackeducation.com/2013/03/03/ hacking-your-education-stephens-hole-in-the-wall-mitra/, accessed 26 February 2014.

33 Edgecliffe-Johnson, A. and Cook, C., (2013), 'Education: From blackboard to Keyboard', Financial Times, 17 January, http://www.ft.com/intl/cms/s/0/8de6072c-60a0-11e2-a31a00144feab49a.html\#axzz2xRMcKT7Q;

Dembosky, A. (2013) 'Celebral circuity', Financial Times, 3 January, http://www.ft.com/intl/ cms/s/0/c19b2e1e-5595-11e2-bbd1-00144feab49a.htm|\#axzz2xRMcKT7Q;

Bairdazzi, M., (2013), 'Liberi Uomini in Libero Web', La Stampa, 31 Marzo, http://www. lastampa.it/2013/03/31/cultura/liberi-uomini-in-libero-web-9L73YFsrkaE2gYApNLPzGI/ pagina.html.

34 Dembosky, A. (2013) 'Celebral circuity', Financial Times, 3 January, http://www.ft.com/intl/ cms/s/0/c19b2e1e-5595-11e2-bbd1-00144feab49a.htm|\#axzz2xRMcKT7Q.

35 Sharples, M., McAndrew, P., Weller, M., Ferguson, R., FitzGerald, E., Hirst, T. and Gaved, M., (2013), Innovative Pedagogy 2013, Open University, http://www.open.ac.uk/personalpages/ mike.sharples/Reports/Innovating_Pedagogy report 2013.pdf, accessed 3 March 2014.

36 Institute of Museum and Library Services, (2009), Museums, Libraries, and 21st Century Skills, Washington D.C., http://www.imls.gov/assets/1/AssetManager/21stCenturySkills. pdf;

The Partnership for $21^{\text {st }}$ Century Skills http://www.p21.org/; Ministry of Education Singapore, 'MOE to Enhance Learning of 21st Century Competencies and Strengthen Art, Music and Physical Education', press release 2010, http://www.moe.gov.sg/media/press/2010/03/ moe-to-enhance-learning-of-21s.php.

37 Tinkering activities were devised first by the Exploratorium of San Francisco Tinkering Studio and from there taken all over the globe, http://tinkering.exploratorium.edu/.

38 Dembosky, A. (2013) 'Celebral circuity', Financial Times, 3 January, http://www.ft.com/intl/ cms/s/0/c19b2e1e-5595-11e2-bbd1-00144feab49a.html\#axzz2xRMcKT7Q.

39 A fundamental aspect of Tinkering as a learning approach is the facilitation of the learning experience, an aspect strongly addressed by museums in all their learning work, and through a range of methods. Facilitation has an invaluable role in creating inclusive and empowering situations building on, and encouraging learners to expand, their personal 
repertoires of knowledge, skills and practice. Facilitation requires a dedicated discussion and is not the prime focus of this paper. On this topic see Xanthoudaki, M., (in press), 'User-Generated' Educators: The New Frontier or a Far-Fetched Dream?' in Patrick, P. (ed) Preparing Informal Science Educators, Springer.

40 Resnick, M., (2007), 'All I Really Need to Know (About Creative Thinking) I Learned (By Studying How Children Learn) in Kindergarten', Creativity and Cognition Conference, http:// web.media.mit.edu/ mres/papers/kindergarten-learning-approach.pdf.

41 Carlo Riva, Director of the Association 'L'Abilità' for children with learning disabilities, press conference of the education programme "Scienzabile", National Museum of Science and Technology, 11 March 2014.

42 European Union Committee of the Regions, (2011), How to promote active ageing in Europe, http://www.google.it/uVf7JDoXUOt7OgcgL\&u

43 Department for Innovation, Universities and Skills (2008) A vision for Science and Society, A Consultation on developing a new strategy for the UK, from Science and Society and dialogue, http://webarchive.nationalarchives.gov.uk/tna/+/http://www.dius.gov.uk/ consultations/documents/A Vision for Science and Society.pdf/;

Irwin, A., (2001), 'Constructing the scientific citizen: science and democracy in the biosciences', Public Understanding of Science, 10 1-18, http://www.outreach.psu. edu/programs/rsa/files/reading_irwin alan_constructing the scientific citizen_public understanding of science 2001.pdf;

Expert Group on Science and Governance (2007) Science and Governance: Taking European knowledge society seriously, European Commission DG Research http://ec.europa.eul research/science-society/document library/pdf 06/european-knowledge-society en.pdf;

Royal Society, (2004), Report Science in Society http://royalsociety.org/uploadedFiles/ Royal Society Content/Influencing Policy/Themes and Projects/Themes/Governance/ Science in Society rev.pdf;

Whitmarsh, L. and Kean, S., (2005), Connecting Science: What We Know and What We Don't Know About Science in Society, The British Association for the Advancement of Science, http://psych.cf.ac.uk/home2/whitmarsh/ConnectingScience review.pdf.

Dembosky, A. (2013) 'Celebral circuity', Financial Times, 3 January, http://www.ft.com/intl/ cms/s/0/c19b2e1e-5595-11e2-bbd1-00144feab49a.htm|\#axzz2xRMcKT7Q.

45 Wu, T., (2014), 'As Technology Gets Better, Will Society Get Worse', The New Yorker, 6 February, http://www.newyorker.com/online/blogs/elements/2014/02/as-technology-getsbetter-will-society-get-worse.html

46 See for example the 'Artefacts of Encounter' Research Programme of the University of Cambridge, http://maa.cam.ac.uk/aofe/.

Rosin, H., (2013), 'The Touchscreen Generation', The Atlantic, 20 March, http://www. theatlantic.com/magazine/archive/2013/04/the-touch-screen-generation/309250/;

Wu, T., (2014), 'As Technology Gets Better, Will Society Get Worse', The New Yorker, 6 February, http://www.newyorker.com/online/blogs/elements/2014/02/as-technology-getsbetter-will-society-get-worse.html.

48 Institute of Museum and Library Services, (2009), Museums, Libraries, and 21st Century Skills, Washington D.C., http://www.imls.gov/assets/1/AssetManager/21stCenturySkills. pdf. 
49 Sharples, M., McAndrew, P., Weller, M., Ferguson, R., FitzGerald, E., Hirst, T. and Gaved, M., (2013), Innovative Pedagogy 2013, Open University, http://www.open.ac.uk/personalpages/ mike.sharples/Reports/Innovating_Pedagogy report 2013.pdf, accessed 3 March 2014.

50 European Union Committee of the Regions, (2011), How to promote active ageing in Europe, http://ec.europa.eu/social/BlobServlet?docld=7005\&langld=en

51 The European Commission Third Demography Report (published April 2011) revealed that the percentage of the EU population aged $65+$ increased from $13.7 \%$ in 1990 to $17.4 \%$ in 2010 . Predictions are that, by 2060 , about $30 \%$ of the EU population will be aged $65+$. The rise of the 'oldest old' - those aged $80+-$ is particularly significant and is forecast to increase fourfold from 1990 to 2060. See European Union Committee of the Regions, (2011), How to promote active ageing in Europe, http://ec.europa.eu/social/ BlobServlet?docld $=7005 \&$ langld $=e n$

52 The European Commission Third Demography Report (published April 2011) revealed that the percentage of the EU population aged 65+ increased from $13.7 \%$ in 1990 to $17.4 \%$ in 2010 . Predictions are that, by 2060 , about $30 \%$ of the EU population will be aged $65+$. The rise of the 'oldest old' - those aged $80+-$ is particularly significant and is forecast to increase fourfold from 1990 to 2060. See European Union Committee of the Regions, (2011), How to promote active ageing in Europe, http://ec.europa.eu/social/ BlobServlet?docld=7005\&langld=en

53 MOV Museum of Vancouver Blog, 'The City as Museum and the Museum as City' 2012, http://www.museumofvancouver.ca/programs/blog/2012/11/2/city-museum-and-museumcity, accessed 25 March 2014.

54 Peel, Y., 'How Museums Can Transform the Art of Learning', CNN Business360, 24 January 2013, business.blogs.cnn.com/2013/01/24/how-museums-can-transform-the-artof-learning/, accessed on 12 February 2014.

55 Weil, S., (1997), 'The Museum and the Public', Lecture at Teachers' College, Columbia University, delivered 2April 1997, http://artsandcultureresearch.org/research/the-museumand-the-public/, accessed 3 February 2014.

56 Centre for the Future of Museums, 'Why You Don't Want to be Nice', American Alliance for Museums Centre for the Future of Museums blog 23 January 2014, http://futureofmuseums. blogspot.it/2014/01/why-you-dont-want-to-be-nice.html, accessed 28 February 2014

\section{Acknowledgements}

I would like to thank the people who accepted my request to read initial drafts of this paper: Heather King, Research Associate at King's College London, Fiorenzo Galli, Director General of the National Museum of Science and Technology Leonardo da Vinci, Massimo Russo, Director WIRED Italy, Francesco Samorè, Scientific Director Fondazione Bassetti.

\section{References}

Adelman, L.M., Falk, J.H. and James, S., (2000), 'Impact of National Aquarium in Baltimore on Visitors' Conservation Attitudes, Behaviour and Knowledge,' Curator, 43(1), 3361.

Beghetto, R.A. (2014) 'The Exhibit as Planned Versus the Exhibit as Experienced', Curator $57(1) 1-4$. 
Bell, P., Lewenstein, B., Shouse, A.W. and Feder, M.A., (2009), (eds), Learning Science in Informal Environments: People, Places, Pursuits, National Research Council, Washington DC: National Academies Press, http://www.nap.edu/catalog. php?record id=12190\#toc.

Bevan, B., Gutwill, J.P., Petrich, M. and Wilkinson, K., (2015), 'Learning Through STEMRich Tinkering: Findings From a Jointly Negotiated Research Project Taken Up in Practice', Science Education, 99(1) 98-120.

Bevan, B. \& Xanthoudaki, M., (2008), 'Professional Development for Museum Educators: Unpinning the Underpinnings', Journal of Museum Education, 33 (1) 107-120.

Black, G., (2012), 'Museums and Participation', keynote paper presented at the Visitor Studies Group AGM, London 3 February.

Blatchford, I., (2014), 'Science Weekly podcast: What Are Science Museums For?' The Guardian, Interview, 3 March, http://www.theguardian.com/science/audio/2014/ mar/03/science-weekly-podcast-museums-ian-blatchford.

Bradshaw, T., (2013), 'Google Accelerates Glass Rollout', Financial Times 29 October, http://www.ft.com/int//cms/s/0/f8c6858a-4001-11e3-a890-00144feabdc0. html\#axzz2u4WfFR2F.

Caban, G., Scott, C., Falk, J.H. and Dierking, L.D, (2003), (eds), Museums and Creativity: A study into the Role of Museums in Design Education, Sydney, AU: Powerhouse Publishing.

Dierking, L., (2010), Being of Value: Intentionally Fostering and Documenting Public Value, Journal of Museum Education, 35(1), 9-20.

European Commission, (2006), Efficiency and equity in European education and training systems, Communication from the Commission to the Council and to the European Parliament, COM (2006) 481 final, SEC (2006) 1096.

Falk, J.H. and Dierking, L.D., (1992), The Museum Experience, Washington D.C: Whalesback Books.

(2000), Learning from Museums, Walnut Creek: Altamira Press.

(2010), 'The 95 Percent Solution', American Scientist 98, 486-493.

Falk, J.H. and Sheppard, B.K., (2006), Thriving in the Knowledge Age: New Business Models for Museums and Other Cultural Institutions, Lanham MD: Altamira Press.

Fischer, G., (2011), 'Understanding, Fostering and Supporting Cultures of Participation', Interactions, 18(3) 42-53, http:///3d.cs.colorado.edu/ gerhard/papers/2011/ interactions-coverstory.pdf.

Gauntlett, D., (2011), Making is Connecting, Cambridge: Polity Press.

Gibbons M., C. Limoges, H., Nowotny, S., Schwarztman, P., Scott and Trow, M., (1994), The New Production of Knowledge: the Dynamics of Science and Research in Contemporary Societies, London: Sage.

Hein, G. E., (1998) Learning in the Museum, London: Routledge.

Honey, M. and Kanter, D.E., (eds), (2013), Design Make Play: Growing the Next Generation of STEM Innovators, New York: Routledge. 
Janes, R.R., (2011), 'Commentary: Museums and the New Reality', Museums and Social Issues, 6(2) 137-146.

Kinsley, R.P. and Wittman, A., (2013), 'Introduction', Museums and Social Issues, 8(2) 3-5.

Libow Martinez, S. and Stager, G., (2013), Invent to Learn: Making, Tinkering and Engineering in the Classoroom, Torrance: Constructing Modern Knowledge Press.

Mahizhnan, A., (1999), 'Smart cities: The Singapore case', Cities, 16(1), 13-18, http:// lkyspp.nus.edu.sg/wp-content/uploads/2013/04/pa Arun Smart-Cities-TheSingapore-Case 99.pdf.

McArdle, M., (2014), The Up Side of Down: Why Failing Well is the Key to Success, New York: Viking.

Museums Association (2013), Museums Change Lives: The MAs Vision for the Impact of Museums, Museums Association.

Nowotny, N., Scott, P. and Gibbons, M., (2003), 'Introduction: "Mode 2" revisited: The new production of knowledge', Minerva, 41, 179-194.

Osborne, J. and Dillon, J., (2008), Science Education in Europe: Critical reflections, $A$ Report to the Nuffield Foundation, http://www.nuffieldfoundation.org/fileLibrary/pdf/ Sci Ed in Europe Report Final.pdf accessed January 2015.

Palacios-Huerta, I., (ed), (2014), In a Hundred Years: Leading Economists Predict the Future, Boston: MIT press.

Papert, S., (2000), 'What's the big idea? Toward a pedagogy of idea power', IBM Systems Journal, 39(3-4) 720-729, http://llk.media.mit.edu/courses/readings/Papert-Big-Idea. pdf.

Pellegrino, J.W. and Hilton, M.L., (eds), (2012), Education for Life and Work: Developing Transferable Knowledge and Skills in the 21st Century, Washington, DC: The National Academies Press, http://www.nap.edu/openbook.php?record id=13398.

Petrich, M., Wilkinson, K. and Bevan, B., (2013), 'It Looks Like Fun but Are They Learning?', in Margareth Honey and David E. Kanter, (eds), Design Make Play: Growing the Next Generation of STEM Innovators, 12-16, New York: Routledge.

Price, D., (2013), Open: How Well We'll Work, Live and Learn in the Future, Great Britain: Crux Publishing.

Resnick, M. and Rosenbaum, E., (2013), 'Design for Tinkerability', in Margareth Honey and David E. Kanter, (eds), Design Make Play: Growing the Next Generation of STEM Innovators, 12-16, New York: Routledge.

Roberts, R.C., (2013), 'Questions of Museum Essence: Being, Being With, and Finding Connection in Conversation', Museums and Social Issues, 8(2) 89-101.

Robinson, K., (2009), The Element: How Finding Your Passion Changes Everything, London: Penguin.

Salomon, G. and Almog T., (1998), 'Educational Psychology and Technology: a Matter of Reciprocal Relations', Teachers College Record, 100(1) 222-241.

Semper, R., (2014), 'Preface' in Karen Wilkinson and Mike Petrich, (eds), The Art of Tinkering, 10, San Francisco: The Exploratorium. 
Shapiro, J. M., (2005), Smart cities: Quality of Life, Productivity and the Growth Effects of Human Capital, National Bureau of Economic Research Working Paper 11615, http://www.nber.org/papers/w11615.

Tennant, M., (1988, 1997), Psychology and Adult Learning, London: Routledge.

The Economist. (2014), 'The future of jobs: The Onrushing Wave', The Economist, 18 January, http://www.economist.com/news/briefing/21594264-previous-technologicalinnovation-has-always-delivered-more-long-run-employment-not-less.

Wilkinson, K. and Petrich, M., (eds), The Art of Tinkering, 10, San Francisco: The Exploratorium.

Winne, B. and Felt, U., (2007), Science and Governance: Taking European knowledge society seriously, European Commission DG Research.

Wood, E. and Wolf, B., (2008), 'Between the Lines of Engagement in Museums: Indiana University and The Children's Museum of Indianapolis', Journal of Museum Education, 33(2) 121-130.

Worts, D., (2011), 'Museums Rising to the Challenge of "Social Relevance Circa 2012"', Museums \& Social Issues 6(2) 219-227.

Xanthoudaki, M., (2013), 'I servizi educativi danno l'anima ai musei. L'educazione nel Museo Nazionale della Scienza e della Tecnologia Leonardo da Vinci: 60 anni di servizio all'apprendimento', Museologia Scientifica, 7 (1-2) 79-86.

Xanthoudaki, M., (in press), 'User-Generated' Educators: The New Frontier or a FarFetched Dream?' in Patrick, P. (ed) Preparing Informal Science Educators, Springer.

*Maria Xanthoudaki is Director of Education \& CREI (Centre for Research in Informal Education), National Museum of Science and Technology Leonardo da Vinci and teaches 'Research Methods in Education' at the Department of Education, Catholic University Milan.

Maria holds a BA in Pedagogy from the University of Crete (Greece), an MA in Arts Education and a PhD in Museum Education, both from the University of Sussex (UK). She has done research on informal learning methodologies and held training courses in museums and universities in the UK, Italy and Greece, beginning with the art museum field and afterwards moving to science museums in 2001.

Dr Maria Xanthoudaki

Director of education and of the centre of research in informal education (CREI) Museo Nazionale della Scienza e della Tecnologia Leonardo da Vinci via San Vittore 21 - 20123 Milano

Tel +390248555304

Fax +390248010016

xanthoudaki@museoscienza.it 